\title{
Sounds of Freedom: Songs in the 1960s Southern Civil Rights Movement
}

\author{
Anne STEFANI \\ Université de Toulouse-Jean Jaurès, France \\ Département d’Études du Monde Anglophone \\ anne.stefani@orange.fr
}

\begin{abstract}
Songs are part of a long tradition of dissent and struggle in American culture since the seventeenth century. In the twentieth century, this tradition is well illustrated by the Freedom Songs of the 1960s civil rights movement, a distinctive feature of the struggle for black freedom in the South. Freedom Songs were used within and outside the movement to sustain as well as to publicize the struggle. The present article analyzes the nature and function of those songs, demonstrating that they represented much more than protest songs. It shows that beyond their most obvious function, which was to mobilize and cement collective participation in the various demonstrations and actions of nonviolent resistance to segregation, Freedom Songs had a transforming power over individuals. In the context of the southern Freedom Movement, singing became an existential experience, a second birth through which African Americans re-appropriated their culture and constructed a new identity for themselves and for their people. Freedom Songs thus can be said to have contributed not only to defeating white supremacy in the South but also to empowering African Americans by reconnecting them to their culture and by providing each individual the way to achieve his or her inner liberation.
\end{abstract}

Keywords: Freedom Songs, Civil rights movement, Nonviolence, Spirituality, African American culture

Songs have been part of a long tradition of dissent and struggle in American culture since early American history. From slave songs to rock music through folk music and Freedom Songs, singing has been a natural means to endure, to resist, to protest oppressing conditions and policies in various periods of American history. In the 1950s and 1960s, starting with the Montgomery Bus Boycott, then through the sit-ins, the Freedom Rides, the Albany Movement, and all following nonviolent actions, Freedom Songs became a distinctive feature of the struggle for black freedom in the South. ${ }^{1}$ They were used within and outside the civil rights movement to sustain as well as to publicize the struggle. These songs originated in church mass meetings to become the driving force of direct action, a dynamic force that made action possible

\footnotetext{
${ }^{1}$ For a good historical account of the civil rights movement and the songs that shaped it, see Carawan, Preface to the 2007 edition. 
and contributed to the various victories of the movement. The music of the movement was no entertainment, neither was it a marginal byproduct of the black struggle in the 1950s and 1960s. For the nonviolent activists and volunteers of the southern civil rights movement, singing constituted an existential experience through which they staged the American drama of racial oppression, resistance, and liberation. Freedom songs were first and foremost part of the myriad local direct actions that occurred in the South between the mid-1950s and the late 1960s, but they soon became a means to sensitize American audiences when Freedom Singers started touring the country to perform as the voice of the nonviolent movement. The present article examines in depth the nature and function of these songs in order to demonstrate that they represented much more than an expression of protest. This article argues that beyond their most obvious function, which was to mobilize and cement collective participation in the various demonstrations and actions of nonviolent resistance to segregation, Freedom Songs had a transforming power over the individuals who sang them and on those who heard them. In the context of the southern Freedom Movement, singing became a cathartic experience, a second birth through which African Americans grew into a new awareness of their culture and constructed a new identity, not only for themselves but also for their people. Through such individual and collective liberation from a history of oppression, Freedom Songs thus contributed to defeating white supremacy in the South while empowering African Americans by reconnecting them to their culture.

The contents of Freedom Songs varied throughout the 1950s and 1960s, but they all shared a few characteristics that made them a distinctive feature of the civil rights movement. The most obvious source of inspiration for these songs, although not the only one, was African American religion. The centrality of religion and spirituality in the nonviolent civil rights movement has led some historians to equate the movement with a religious revival. Questioning the dominant historiography defining the 1960s movement as a social movement, David Chappell argues:

To take the testimony of intense religious transformation seriously is to consider the civil rights movement as part of the historical tradition of religious revivals, such as the so-called First and Second Great Awakenings, as much as it is part of the tradition of protest movements such as abolitionism, populism, feminism, and the labor movement. (2004: 87)

The "intense religious transformation" Chappell refers to took many forms but was most likely to occur during the act of singing. ${ }^{2}$ What came to be known as "Freedom

\footnotetext{
${ }^{2}$ For instance, John Lewis, chair of the Student Nonviolent Coordinating Committee (SNCC) from 1963 to 1966, remembers how Robert Moses (another SNCC leader) once "stood up and took a soft drink bottle with water - he said it was wine but it was not wine - and started singing and marching 
Songs" in the 1960s cannot be dissociated from the African American religious tradition, sacred and Gospel music being the main source of inspiration for the singers of the southern civil rights movement. Although, in the previous decades, a majority of black churches had dissociated themselves from civil rights activism for fear of reprisals, the minority of ministers who did challenge segregation - and became leaders of the struggle for freedom - offered their churches for mass meetings that sustained the nonviolent movement from the Montgomery Bus Boycott on (Lincoln and Mamiya 1990: 209-12). The organization of mass meetings was patterned on traditional church services, starting and finishing with prayer and music, based on the traditional Protestant hymnody dating back to the nineteenth century (Harvey 2005: 172). ${ }^{3}$ Bernice Johnson Reagon, who became a Freedom Singer in Albany, Georgia, in 1961, and joined the Student Nonviolent Coordinating Committee (SNCC) in 1962, later studied the role of songs in the movement and their significance in African American cultural history. ${ }^{4}$ Drawing both from her personal experience and her research, she emphasizes the importance of churches in the development of Freedom Songs:

Again and again, it was to the church that the movement activists came for physical protection and spiritual nurturing - the very structure developed by the Afro-American community for the survival of its people. The church provided the structure and guidance for calling the community together; it trained the singers to sing the old songs and gave them permission to create new ones (qtd. in Carawan 2007: xxi).

Songs left the traditional setting of churches with the spread of the sit-in movement and of the Freedom Rides in 1960 and 1961. The students who resorted to nonviolent direct action to fight for the desegregation of eating places and interstate transportation also took the habit of singing during their actions, and continued to sing in jail after being arrested. The transcending power of such singing deeply impressed the few white students that found themselves locked up in separate cells but could hear their black fellow activists sing from cell to cell. Such was the case of Joan Trumpauer Mulholland, a white Freedom Rider who was arrested and jailed in Jackson, Mississippi, in June 1961. She wrote in her diary that hearing those black voices from her cell "was one of the most uplifting experiences [she'd] ever had" (qtd.

around the room with a lot of people. It was like being in a revival where the minister saves the souls of the sick" (qtd. in Chappell 2004: 92).

${ }^{3}$ See Bettie Mae Fikes' testimony about the Selma Youth Movement. She explains, for example, that the young freedom activists of Selma created a freedom choir and turned the traditional "This Little Light of Mine” into a Freedom Song (Holsaert 2010 : 466-67). After the movement, Bettie Mae Fikes pursued a career as a gospel and blues singer.

${ }^{4}$ See her Ph.D. dissertation, "Songs of the Civil Rights Movement 1955-64: A Study in Culture History,” Ph.D. diss., Howard University, 1975. Reagon, who continued to sing after the movement, also became a cultural historian and served as a curator for the National Museum of American History. 
in Holsaert 2010: 73). ${ }^{5}$ A majority of the students who constituted the shock troops of the nonviolent movement between 1960 and 1964 were native southerners steeped in Protestant religion, and their activism was fueled by the Christian values they had learned since childhood. Believers in nonviolence as a way of life, such as John Lewis, aimed at applying such values to secular society. ${ }^{6}$ They actually transformed the traditional religion into what they called "soul force" or "the spirit" (Lewis 1998: 78), i.e. a profound faith in freedom, of which Freedom Songs became the incarnation. Lewis remembers the church of his childhood, "vibrant" with "pure singing, the sound of voices fueled by the spirit, people keeping rhythm with a beat they heard in their hearts, singing songs that came straight from their soul, with words they felt in every bone of their body" (1998: 20-21). Lewis' testimony suggests that, in such a context, singing took on a definite theatrical dimension, the participants literally acting out their faith. Singing was part of the activists' everyday life, and they came to adapt the traditional songs to local circumstances, thus giving birth to a new and unique repertoire. The Albany movement of 1961-62 marked a turning point in that respect because it was there that Freedom Songs became openly identified with the struggle against segregation, since groups of Freedom Singers, who later toured the country to publicize the Movement and raise funds, ${ }^{7}$ were formed at that time.

Moreover, if black church music was the major inspiration for Freedom Singers, civil rights activists also drew from other traditions, such as popular music especially Rhythm and Blues (Hartford 2011). Bernice Johnson Reagon testifies:

All of the songs were not church songs. Because all of the people in the Movement were not church people. So the songs came right off the radio and the most popular person who delivered songs to the Movement was a man named Ray Charles. I don't think he knew he was delivering songs to the Movement, but Ray Charles represents a synthesis of what was happening in the Black community (qtd. in Greenberg 1998: 119).

The popular music of the 1950s and 60s actually intersected with various trends of religious music, especially those that had transformed black evangelical worship in the previous decades. Black southern evangelical Protestantism in particular had been influenced by the rise of Pentecostal worship, which encouraged audience

\footnotetext{
${ }^{5}$ On the transforming power of singing on the whites who attended church meetings, see Watters: "Such music cannot be described-or recaptured. It was there. I heard it, was privileged to hear it night after night in the packed-in heat. And even now, hearing it more thinly on tapes, I return to the mystical, inspired and excited, ecstatic — and reverent mood of those meetings" (1971 : 180)

${ }^{6}$ Lewis, who has achieved national prominence as a Representative from Georgia in the U.S. House of Representatives, recounts his experience of the civil rights movement and reflects on its meaning in his memoir, Walking with the Wind (see References).

${ }^{7}$ The original group of Freedom Singers, formed in Albany in 1961, included Bernice Reagon, Rutha Harris, Cordell Reagon, and Chuck Neblett (Carawan 2007 : xiv).
} 
participation, call-and-response, foot-stomping and hand-clapping (Harvey 2005: 165). Gospel music and blues also crossed paths with classical religious music in the twentieth century (Harvey 2005: 151), as many preachers also happened to be bluesmen. According to historian Paul Harvey, "the blues and religion competed for souls. [...] Many bluesmen saw themselves as the conscience of the community, at the periphery of alternative forms of Christianity and alternative forms of supernaturalism" (2005: 159). He goes on to explain that in the early twentieth century, "Rural southern bluesmen served as folk theologians. They explored the nature of good and evil, commented profoundly on the nature of human relationships, and lampooned the hypocrisies of supposedly respectable community leaders. The preachers and bluesmen saw themselves as ferocious competitors in a zero-sum game” (2005: 160).

The rise of black gospel music in the early twentieth century thus reflected the intersecting influences of blues and religious music on southern popular culture, and gospel music in turn influenced the secular popular music taken over by Freedom activists in the 1960s. Hence Bernice Reagon's perception of Ray Charles' music: "Ray Charles started 'Drown in My Own Tears,' it sounded like gospel. Well, what is he doing? Is he singing blues? Is he singing reals, or is this gospel?” (qtd. in Greenberg 1998: 119). Another musician and veteran of the civil rights movement, James "Sparky" Rucker - who notably worked with SNCC and with the Highlander Folk School ${ }^{8}$ - emphasizes the close ties that still existed between religious and secular music (especially Rhythm and Blues) in the 1960s' South:

Some of the people would come south from the North to sing some of the songs, and some of the people from the South would sing the southern songs. Let them know you didn't have to go get Pete Seeger, you could just get old Reverend Brother Brown down in Americus, Georgia. He's the man who taught me how to play this old bottleneck guitar. (qtd. in Greenberg 1998: 123)

Rucker's comment incidentally reveals that the religious dimension of Freedom Songs had much to do with the southern background of the activists who sang them, southern culture being itself steeped in religion. ${ }^{9}$

Finally, the labor tradition constituted another major source of inspiration for the civil rights movement, with songs such as "We Shall Not Be Moved," a traditional song adapted in 1909 by the garment workers of New York's Lower East side, or "Which Side Are You On?" sung by the members of United Mine Workers in Harlan

\footnotetext{
${ }^{8}$ Founded in 1932 in the mountains of Tennessee, the Highlander Folk School first worked with labor unions to provide southern workers with the means to struggle for social justice. From the 1950s on, it focused on desegregation and actively supported the civil rights movement. For further information about the school, see Adams.

${ }^{9}$ See Harvey 2011 for an in-depth analysis of the South’s religious culture.
} 
County, Kentucky, in 1931 (Hartford 2011). "We Shall Overcome” is the most emblematic one. Originally a slave work song, it was published as a hymn, "I'll Overcome Someday," then became "We Will Overcome" after the black members of the Food and Tobacco Union in South Carolina took it over in 1945. The leaders of the Highlander Folk School ${ }^{10}$ later adapted it for the civil rights movement. Septima Clark, of the Southern Christian Leadership Conference (SCLC), changed "will" into "shall," folk singer Pete Seeger and others added verses, and it finally ended up in Albany, Georgia, where the singers slowed the tempo and gave it the form that became the anthem of the 1960s Movement (Hartford 2011). The case of the Highlander Folk School is especially interesting here because its leaders drew their philosophical inspiration from both the American religious and labor traditions. Having used music and songs as a privileged tool through their work with the labor movement, the leaders of the school set up singing workshops in the 1960s to sustain the civil rights movement. Guy and Candie Carawan, who worked for Highlander at that time, later published a story of the movement based on Freedom Songs (Carawan 2007: xiii, Adams 1998: 154-57).

The examples mentioned above show that most Freedom Songs were a combination of spirituals, popular music, and protest songs, adapted to the conditions and events of the 1950s and 1960s. Singers typically found themselves in a specific context and started to sing the original song, then changed the lyrics in order to make them fit the place, the events, and the people present on the spot at the time. Rutha Mae Harris, a regular participant of the Albany Movement, remembers: "We took our church songs and made them fit the occasion. For instance, in the song 'Ain't Gonna Let Nobody Turn Me 'Round,' the original version says 'marching up to Canaan land.' In Albany we changed the lyric to 'marching up to freedom land'” (qtd. in Holsaert 2010: 145). In other versions applied to other events and settings, the same original song was adapted to defy all things and people who stood in the way of the civil rights movement. The word "nobody" in the first verse was replaced in the following verses by "racism, violence, cops, Klansmen, Governor Wallace, etc." (Hartford 2011). ${ }^{11}$ These testimonies demonstrate that during the civil rights movement singing often turned into an improvisation performance. Harris adds that they also "created songs for a specific situation," like "We'll Never Turn Back,"

\footnotetext{
${ }^{10}$ See note 7 .

${ }^{11}$ The first stanza reads as follows: “Ain't gonna let nobody, turn me 'round/ Turn me 'round, turn me 'round./ Ain't gonna let nobody, turn me 'round./ Keep on a-walkin', keep on a-talkin'/ Walkin' into freedom land” (“Ain’t Gonna”). Many lyrics are available on the same website, American Experience (see References), as well as in Carawan 2007, and in Seeger and Reiser 1990. Many audio files are also available online (see, for instance, American Experience, "Soundtrack for a Revolution," or Interactive Jukebox, "The Civil Rights Movement”), or in audio CD format (see Various Artists in References). For further analysis of the lyrics, see Sanger 1995.
} 
about the murder of Herbert Lee in McComb, Mississippi (qtd. in Holsaert 2010: 145). The creation of original songs further testifies to the dynamic character of the singing experience that occurred during the civil rights movement. The old repertoire actually served as a cultural matrix from which young civil rights activists could create a new identity for themselves while keeping connected to the previous generations.

From the many testimonies of people who participated in nonviolent actions in many different places throughout the civil rights movement, it is clear that the most obvious function of Freedom Songs was to maintain unity and solidarity within the movement, while giving people the courage to face the violence of white supremacists and to go on fighting. "Freedom Songs suffused each singer with the summed power of the whole," Bruce Hartford writes. Hartford was involved in the Congress of Racial Equality (CORE) and the SCLC from 1963 to 1967. He comments on the Freedom Songs in the following words:

They wove into a single Freedom Movement the adults who sang them in mass meetings, the young militants who carried them into jail, and the local activists who raised them in small circles of courage surrounded by danger. [...] As the furnace-fire turns iron ore into steel, singing our shared songs forged bonds of loyalty that for many of us have not withered with age in five decades. (2011)

Another SNCC veteran organizer, Sam Block, observes that music not only brought people together but provided the "organization glue to hold them together" (qtd. in Hartford 2011). Such a function was vital because it prevented the disintegration of the movement, which was characterized by a great diversity of opinions and attitudes and, as a result, by permanent tensions and conflicts. Music did not erase conflicts but transcended them, as Bernice Reagon explains: "You see all these Black people and we're singing together, it looked like we all had erased all the friction - that is a façade. That is not what the singing does. The singing suspends the confusion and points to a higher order, sometimes long enough for you to execute the next step" (qtd. in Greenberg 1998: 119). Another very practical function of Freedom Songs had to do with the tactics of nonviolent action. Bruce Hartford describes Freedom Songs as the "emotional" arm of nonviolent marches and demonstrations, which allowed demonstrators to dramatize the ideas of the movement. The psychological impact of songs, he explains, is much more powerful than slogan chanting, because songs last longer and convey a whole range of ideas and emotions. This is confirmed by Guy Carawan, of the Highlander Folk School. Recalling a nonviolent demonstration during the Nashville movement, he comments on the immediate, physical impact of singing. "I think I ran into C. T. Vivian for the first time in front of the mayor's office in Nashville," he says. "It was probably the first time that 'We Shall Overcome' was used at a mass gathering as part of that movement, and you could see tears in people's eyes. Singing really had that kind of impact” (qtd. in Adams 1998: 155). Songs also 
sound much less threatening to bystanders, observers, and even the police, because they are less hostile than shouted slogans. In some cases, singing protected demonstrators from direct violence because it created a "psychic wall" which the enemies could not breach (Hartford 2011). Thus, Freedom Songs partook of the overall nonviolent strategy of confrontation, being both a weapon and a shield for the demonstrators.

Moreover, if Freedom Songs played an essential practical role in the successful campaigns of the civil rights movement throughout the 1950s and 1960s, they also had much deeper functions for the people who sang them. The way veterans of the civil rights movement describe their experiences shows that singing during the movement amounted to an existential act of personal and collective liberation that transformed them forever. Several veterans first insist on the fact that Freedom Songs were unique because they were not to be performed for an audience. Singing was a creative act in which all the people present participated:

Sometimes professional performers sang political songs for listening audiences - Nina Simone's Mississippi Goddam, Sam Cooke's A Change Is Gonna Come, Bob Dylan's Blowing in the Wind - but when Movement veterans speak of "freedom songs" we mean the songs that we all sang together. Songs that we sang, not as a performance for the entertainment of others, not as something to be passively listened to, but as something we ourselves created anew each time we lifted our voices. And it was the act of singing, more than the beauty of the songs, that gave them meaning and power. (Hartford 2011)

Singing was thus a transformative act that took on a cathartic dimension in the sense that it allowed the singers to transcend a specific situation, and in the process to transcend their own condition of oppressed people by affirming life over death. This again is related to the spiritual dimension of the nonviolent movement, to the notion of soul power, or to what Prathia Hall, a SNCC worker from 1962 to 1966, calls "freedom-faith." Hall explains that the songs that had been familiar to her in her youth took on another dimension and meaning during the Movement:

In this place, Southwest Georgia, with hostile police ringing the exterior of the church, [the songs] were neither repetitious nor familiar; they were worship that contained within the reality of its expression a power affirming life and defying death. That power with which those songs and prayers were infused transcended the objective reality of our situation, fashioned fear into faith, cringing into courage, suffering into survival, despair into defiance, and pain into protest. (qtd. in Holsaert 2010: 174)

Hall's experience is in no way unique since the terms "transcend" and "transcendence" pervade the literature about Freedom Songs. The singer and actor Harry Belafonte uses very similar words to evoke Fannie Lou Hamer's singing, saying: 
When she sang, it transcended all other considerations at the moment. And when she evoked singing at times, I always felt that she felt it was needed in order to break a mood of something that was happening at the moment. That song from the heart would bring another dimension when everybody got back at the end of the song to the business. (qtd. in Mills 2007: 20)

Hamer, who stands out today as one of the key grassroots leaders of the movement, owed much of her inspiring power to her extraordinary singing capacity. ${ }^{12}$

Bernice Reagon goes further in her analysis of Freedom Songs by stressing the deep psychic impact of singing, i.e. a radical transformation of the self:

You are at total risk and you feel you're at total risk, but if you wanted to kill the "you" that you are, you still had to go through it. And there is a promise that you will be different on the other side. Guaranteed. But it's like stepping off a ridge when you can't see the bridge. And since you decided you don't want to be on the ridge anymore, you just step off. And you know if you survive you're going to be fighting all the way. That's what the Movement was like. I am describing not reformation, I'm really describing a revolution that takes place inside of you, if you do it. (qtd. in Greenberg 1998: 116)

In another testimony, Reagon emphasizes the change that occurred in her own perception of traditional church songs when she started to sing for the civil rights movement: "It was like an amazing light of understanding opening up within me. That prayer, which had sounded old, was new and immediate; it was about us, pressed down by racism and wanting the power of the universe to be with us as we marched" (qtd. in Greenberg 1998: 150). Reagon's description almost sounds like a conversion narrative, confirming the idea that mass meetings could be compared to religious revivals.

Moreover, if Reagon and others relate their experiences in very personal terms and stress the importance of Freedom Songs in their transformation as individuals, the veterans also reflect on the collective meaning of those songs and on the role they played in the liberation of black people as a whole, such liberation passing through the assertion of a specific culture rooted in their history of oppression and resistance. The notion of empowerment runs through the various testimonies, as for instance, in the following extract from Andrew Young's memoir:

\footnotetext{
${ }^{12}$ Fannie Lou Hamer was a Mississippi sharecropper who became involved in the civil rights movement when SNCC organized voting registration campaigns in her native state in the early 1960s. In 1964, she worked with SNCC on the "Mississippi Freedom Summer" project and became vice-chair of the Mississippi Freedom Democratic Party that challenged the all-white regular Mississippi delegation at the Democratic National Convention. On the power of Hamer's singing, see Mills 2007: xi, 19-22, 37, 53, 140, 310 .
} 
Somehow through the music a great secret was discovered, that black people, otherwise cowed, discouraged, and faced with innumerable and insuperable obstacles, could transcend all those difficulties and forge a new determination, a new faith and strength, when fortified with song. The music was not a political or economic gift to the people from the authorities, nor could it be taken away by them - music was the gift of the people to themselves, a bottomless reservoir of spiritual power. (qtd. in Harvey 2005: $172)^{13}$

Young's words make it clear that singing was a militant act of self-assertion through which African Americans re-appropriated their past and their identity. ${ }^{14}$ By singing or leading Freedom Songs, people who had never had access to any kind of leadership became civil rights leaders, one of the best illustrations being Fannie Lou Hamer, whose powerful singing turned her into an icon of the Freedom Movement.

The empowerment of individuals soon became interpreted as the empowerment of a whole people, as black people became aware that their actions were rooted in a specific culture that had developed in the South as a response to oppression since slavery times, a culture brought to the surface by songs. Many original songs had been sung by the enslaved ancestors of the people who took them over in the 1960s. Prathia Hall, for instance, traces back her notion of freedom-faith to the antebellum era: "It was a faith first made manifest by our slave fore-parents who defied the teaching of the slavocracy, which distorted the Bible and declared that their slavery had been ordained by God” (qtd. in Holsaert 2010: 176). Others, like Bernice Reagon, emphasize the fact that Freedom Songs reflected the specific nature of black culture, whose participatory dimension distinguishes it, according to her, from mainstream American culture. As she affirms, "Most people learn about what is Black from the commercial industry, which does not want you to know what I'm going to talk about tonight, which is that Black American culture is participatory and you don't go buy Black American culture, you have to create it” (qtd. in Greenberg 1998: 111, emphasis in the original). Furthermore, Reagon declares that

You cannot create a song within the Black American cultural experience if you're not an organizer. You cannot create a song if you're not willing to be organized. You have to hear, you have to be willing to lead, you have to be willing to follow, you have to be

\footnotetext{
${ }^{13}$ Andrew Young, a Protestant minister, worked with Martin Luther King and the SCLC during the 1960s movement, becoming the organization's executive director in 1964. He then pursued a national political career, notably serving as Georgia's representative in the U.S. Congress (1973-77), ambassador to the United Nations (1977-79), and mayor of Atlanta (1982-90).

${ }^{14}$ On music as an empowering force, see also Lincoln and Mamiya 1990: 372-73. They summarize their point in the following words: "The freedom songs did not passively lament the black condition; they made God active in human history day by day with social agitation. African Americans were not just singing about freedom, they were systematically seeking it, and their songs were deliberate instruments tactically utilized in the effort” (1990: 373).
} 
willing to experiment and move around the basic themes. . . . You don't sing Black songs, you raise them, which means they don't exist before they are sung. (qtd. in Greenberg 1998: 112, emphasis in the original)

Reagon's words, and more especially her insistence on the participatory nature of Freedom Songs, could well apply to theater, since one could argue that a play does not exist before it is staged. This confirms the idea that, when the men and women who participated in the nonviolent civil rights movement engaged in singing, they actually staged their liberation by "raising" Freedom Songs as an act of empowerment.

In sum, singing during the civil rights movement was definitely a means for African Americans to liberate themselves, not only by claiming their civil rights but also by asserting a distinctive collective identity that had been repressed by white society and institutions for centuries. They did so by taking traditional songs from the centuries-old African American culture and by giving them new meaning. In the process, the songs they had heard and sung at church since childhood, which had been familiar but totally disconnected from the daily reality of discrimination, became powerful nonviolent weapons through which they could defy their oppressors. Ultimately, singing conferred the activists a new sense of humanity. "I felt I was joining the human race," says Mendy Samstein, "and this was what was so moving and continues to move me" (qtd. in Greenberg 1998: 126). ${ }^{15}$

In the final analysis, although the power and role of Freedom Songs in the civil rights movement has been the object of a few scholarly studies, it remains little known of the general public. They actually constituted the essence of the nonviolent movement. In other words, many of the demonstrations or actions of nonviolent resistance that occurred in the early 1960s would not have succeeded, or they would not have had the impact they had on local communities, had it not been for Freedom Songs. The strength of Freedom Songs lay in their transforming power, not only for the individuals who sang them, but also for the people who heard them. Moreover, if such power was obvious for African Americans, it also affected many whites, bringing to the surface centuries of oppression and resistance that burst out through the voices of the singers. Freedom Songs not only empowered blacks but shook whites into awareness by making them feel the burden of oppression and the power of resistance of the oppressed. Finally, the power of those songs lay in their constituting a synthesis of the spiritual and physical dimensions of nonviolent direct action. By uniting spirit and body, ideals and action, faith and physical strength, Freedom Songs carried civil rights demonstrators to levels of commitment they would never have reached without them.

\footnotetext{
${ }^{15}$ Samstein joined SNCC in 1963 (Greenberg 1998 : 258).
} 


\section{REFERENCES}

Adams, Franck (with Myles Horton) (1998). Unearthing Seeds of Fire: The Idea of Highlander (1975). Winston-Salem, NC: John F. Blair.

Ain’t Gonna Let Nobody Turn me ‘Round. American Experience: Soundtrack for a Revolution. PBS website.

$<$ http://www.pbs.org/wgbh/americanexperience/features/generalarticle/soundtrack-lyrics/\#turn> (Accessed 6 October 6 2013).

American Experience: Soundtrack for a Revolution. PBS website. $<$ http://www.pbs.org/wgbh/americanexperience/features/generalarticle/soundtrack-lyrics/> (Accessed 28 September 2014).

Carawan, Guy and Candie Carawan, eds. (2007) Sing for Freedom: The Story of the Civil Rights Movement Through Its Songs. Montgomery, AL.: New South Books.

Chappell, David (2004). A Stone of Hope: Prophetic Religion and the Death of Jim Crow. Chapel Hill, NC: U of North Carolina P.

Greenberg, Cheryl Lynn, ed. (1998). A Circle of Trust: Remembering SNCC. New Brunswick, NJ, and London: Rutgers UP.

Hartford, Bruce (2011). The Power of Freedom Songs. Civil Rights Movement Veterans Website. <www.crmvet.org/info/fsongs.htm> (Accessed 28 September 2014).

Harvey, Paul (2005). Freedom's Coming: Religious Culture and the Shaping of the South from the Civil War through the Civil Rights Era. Chapel Hill, NC, and London: U of North Carolina P.

Holsaert, Faith S., et al. (2010). Hands on the Freedom Plow: Personal Accounts by Women in SNCC. Urbana, Chicago and Springfield: U of Illinois P.

Interactive Jukebox (2006). The Civil Rights Movement. History Now 8 (Summer), Gilder Lehrman Institute of American History. <http://www.gilderlehrman.org/history-now/2006-06/civil-rights-movement> (Accessed 28 September 2014).

Lewis, John (with Michael D’Orso) (1998). Walking with the Wind: A Memoir of the Movement. New York, San Diego and London: Harcourt Brace.

Lincoln, C. Eric and Lawrence H. Mamiya (1990). The Black Church in the African American Experience. Durham and London: Duke UP.

Mills, Kay (2007). This Little Light of Mine: The Life of Fannie Lou Hamer (1994). Lexington, KY: UP of Kentucky.

Reagon, Bernice Johnson (1975). Songs of the Civil Rights Movement 1955-64: A Study in Culture History. Ph.D. diss., Howard University.

Sanger, Kerran L. (1995). "When the Spirit Says Sing!" The Role of Freedom Songs in the Civil Rights Movement. New York: Garland.

Seeger, Pete and Robert Reiser (1990). Everybody Says Freedom. New York: Norton. Various Artists (1990). Sing for Freedom [sound recording]: The Story of the Civil Rights Movement Through its Songs. Washington, D.C.: Smithsonian Folkways; distributed by Rounder Records. 
Various Artists (1997). Voices of the Civil Rights Movement [sound recording]: Black American Freedom Songs, 1960-1966. Washington, D.C.: Smithsonian Folkways. Watters, Pat (1971). Down to Now: Reflections on the Southern Civil Rights Movement. New York: Pantheon. 